\title{
Public Legal Awareness of the Importance of Covid-19 Vaccination in Southeast Maluku Regency
}

\author{
Yosia Hetharie $^{1^{*}}$, Patrick Corputty ${ }^{2}$ \\ 1, 2, Faculty of Law Pattimura University, Ambon, Indonesia \\ *E-mail: josephushetharie@gmail.com
}

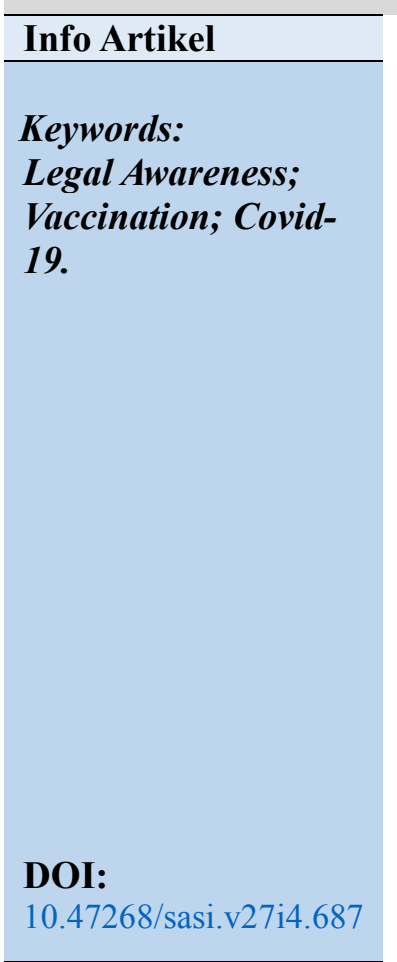

\begin{abstract}
The spread of Covid-19 has an impact on all areas of human life universally throughout the world to all corners of the region in Indonesia, including the Southeast Maluku Regency, Maluku Province. Therefore, the government through the covid-19 vaccination program is one way to break the chain of the spread of Covid-19. This study uses a normative juridical research which is descriptive analytical through primary legal materials and secondary legal materials with literature studies. The analysis used is qualitative analysis. The implementation of the Covid-19 vaccination in Southeast Maluku Regency continues to be carried out in order to meet the national achievement target of $70 \%$. As of early November, it was shown that in Southeast Maluku the achievement rate of Covid-19 vaccination for both the first and second doses was still below the national target of 70 percent. By not meeting the national Covid-19 vaccination achievement target in Southeast Maluku Regency, it shows that the legal awareness of the community to vaccinate Covid-19 in Southeast Maluku is still very minimal. The Southeast Maluku Regency Government needs to approach the community that is more humanistic and socio-cultural in order to provide education and good understanding for the community about the Covid-19 vaccination so as not to cause doubts in the community to vaccinate Covid-19.
\end{abstract}

\section{A. INTRODUCTION}

Around December 2019, the first case of COVID-19 was reported in Wuhan, Hubei Province. The source of the transmission is still unknown, but the first case was linked to a fish market in Wuhan. ${ }^{1}$ Corona Virus Disease-19 (Covid-19) in Indonesia has a bad impact on all aspects of people's lives, the nation and the state including the state economy, banking, to the survival of the community. ${ }^{2}$ The Covid-19 virus is a virus whose spread can move from one community to another not only through the air, but also can be transferred or transmitted by droplets produced when one person is positively infected with the virus then coughs, sneezes

1 Rothan, H. A., \& Byrareddy, S. N. (2020). The epidemiology and pathogenesis of coronavirus disease (COVID-19) outbreak. Journal of autoimmunity, 109, 102433.

2 Tjoanda, M., Hetharie, Y., Pariela, M. V. G., \& Sopamena, R. F. (2021). Covid-19 sebagai Bentuk Overmacht dan Akibat Hukumnya Terhadap Pelaksanaan Perjanjian Kredit. SASI, 27(1), 93-101. 
or talks with other people, then through respiratory droplets or respiratory droplets (droplets) the virus becomes spread and infects others. ${ }^{3}$

This Covid-19 virus can survive in the air for eight hours after leaving the body of a person who is positively infected with the virus through sneezing or coughing and not only requires a liquid medium to survive. A person with Covid-19 who is infected with this virus for the first time can feel various symptoms. These symptoms can be felt after 5-6 days, or no later than 14 days from exposure to this Covid-19 virus. ${ }^{4}$ The various symptoms can consist of mild symptoms such as shortness of breath, sneezing, fever, sore throat and not feeling well. ${ }^{5}$ In addition to mild symptoms, patients exposed to COVID-19 can also experience much more severe symptoms such as bronchitis and pneumonia which can cause symptoms such as a high fever if the patient has pneumonia, cough with mucus, shortness of breath, chest pain or shortness of breath and coughing. This symptom often occurs in patients who are a group of people with congenital diseases such as heart or lung disease, people with weak immune systems, infants, and the elderly.

The spread of the COVID-19 outbreak since the end of 2019 has been felt by the entire world community, including people in Indonesia. ${ }^{6}$ The COVID-29 pandemic has hit Indonesia for almost 2 years. Although up to the time of the COVID-19 pandemic, cases had decreased compared to 2020, but that does not mean that the handling of the COVID-19 pandemic is not a serious concern. Covid-19 has had a major impact on all aspects of Indonesian people's lives. Therefore, handling the impact of the COVID-19 pandemic must be carried out properly, carefully and consider all aspects and risks that arise as well as the benefits that must be felt by all Indonesian people.

Until now, the government continues to make various efforts in order to handle the spike and increase in cases as well as the impact that has arisen due to the COVID-19 pandemic. Various efforts have been made, namely through Large-Scale Social Restrictions (PSBB) in order to anticipate the large number of activities outside the home so that the virus does not spread further, in addition, in the banking sector and government financing, a credit restructuring program for debtors, which is due to the COVID-19 pandemic, has not been implemented. able to perform well. Another program is the movement against covid-19 by implementing the $5 \mathrm{M}$ health protocol (washing hands, wearing masks, maintaining distance, staying away from crowds, reducing mobility). Another program that is no less important is the implementation of the COVID-19 vaccination program. The government is accelerating the vaccination program to immediately achieve herd immunity, because it believes that vaccination has a central role in handling Covid-19 and recovering the national economy. Efforts to overcome the COVID-19 pandemic are not only the responsibility of the government, but also require the role and participation of the community in the context of synergy to reduce the spread of COVID-19.

Community participation and contribution can be shown through concrete actions and actions, for example following all government recommendations and policies by implementing health protocols, even carrying out COVID-19 vaccinations for people who have met the requirements to be vaccinated. The reality and conditions that occur are that there are still many people who do not want to be vaccinated for various reasons, namely fear of the side effects of

3 Ayunda, R., Kosasih, V., \& Disemadi, H. S. (2021). Perlindungan Hukum Bagi Masyarakat Terhadap Efek Samping Pasca Pelaksanaan Vaksinasi Covid-19 Di Indonesia. NUSANTARA: Jurnal Ilmu Pengetahuan Sosial, 8(3), 194-206.

4 Ibid

5 Prajnaparamitha, K., \& Ghoni, M. R. (2020). Perlindungan Status Kerja Dan Pengupahan Tenaga Kerja Dalam Situasi Pandemi COVID-19 Berdasarkan Perspektif Pembaharuan Hukum. Administrative Law and Governance Journal, 3(2), 314-328.

6 Pesulima, T. L., \& Hetharie, Y. (2020). Perlindungan Hukum Terhadap Keselamatan Kerja Bagi Tenaga Kesehatan Akibat Pandemi Covid-19. Sasi, 26(2), 280-285.

457 | S A S Volume 27 Is u e 4, October - D e cember 2021 
vaccination, assuming that vaccines are ineffective and do not provide benefits in terms of handling COVID-19, and assuming that their bodies do not need vaccines because they are in poor condition. Healthy people, some even doubt the halalness of the covid-19 vaccine.

\section{B. RESEARCH METHODS}

This study uses a normative juridical research method, namely the doctrinal law research method that examines, examines and analyzes various provisions of the applicable laws and regulations relating to the problems studied. The nature of the research is descriptive analytical by examining legal materials, both primary legal materials and secondary legal materials through literature studies and other related literature. The analysis used in this research is qualitative analysis to answer the problems studied.

\section{RESULTS AND DISCUSSION}

\section{Implementation of the Covid-19 Vaccination in Southeast Maluku Regency}

In Indonesia, the impact of the Covid-19 pandemic continues to show an increase from time to time at the beginning of the outbreak of the COVID-19 pandemic. The impact of this pandemic has caused great losses, both fatalities and material losses. In addition, the impact of COVID-19 has affected the rate of national economic growth, the number of state revenues has declined, as well as an increase in the state budget, which is focused on handling the spread of the COVID-19 pandemic. Not only that, but the Covid-19 pandemic has also had an impact on the weakening of the state financial system as indicated by a decrease in various domestic economic activities. By looking at the various impacts of the COVID-19 pandemic which have had a major impact on the economy of the nation and state, the government is seeking various policies and efforts to tackle the increasingly widespread spread of the COVID-19 pandemic. Efforts and policies carried out as a form of saving health and the national economy, with a focus on spending on health, social safety nets, and economic recovery, including for the business world and affected communities as well as those that have the potential to disrupt sector resilience and stability. state finances and economy. The above efforts became the basis for consideration for the government so that Government Regulation in Lieu of Law Number 1 of 2020 was issued which was later changed to Law Number 2 of 2020 concerning State Financial Policy and Financial System Stability for Handling the Corona Virus Disease Pandemic. 2019 (Covid-19) and/or In the Context of Facing Threats That Endanger the National Economy and/or Financial System Stability.

In Indonesia itself, one of the policies that is being intensively carried out by the government is through the COVID-19 vaccination program. The legal basis for implementing the COVID-19 vaccination program is through the establishment of Presidential Regulation Number 99 of 2020 which has been revised and strengthened by Presidential Regulation Number 14 of 2021 and implementing regulations / derivatives in Regulation of the Minister of Health Number 28 of 2020 concerning Implementation of Vaccine Procurement in the Framework of Pandemic Management. Covid-19 and Regulation of the Minister of Health Number 84 of 2020 concerning the Implementation of Vaccination in the Context of Combating the Covid-19 Pandemic.

Given the importance of the Covid-19 Vaccine/Vaccination, countries in the world, including Indonesia, make the provision of the Covid-19 Vaccine/Vaccination a priority in overcoming the Covid-29 Pandemic. During 2020 there are several countries that have vaccinated, such as: UK, United States, and Canada. The government will continue to follow the development of vaccinations that have been carried out by various countries as input for the national vaccination program. In Indonesia, the Government has taken policies that are outlined in the form of the Vaccine Procurement Program and the provision of Covid-19 Vaccination as part of the Covid-19 Handling and National Economic Recovery. The administration of the

$$
\text { 458|S ASI Volume } 27 \text { Issue 4, October - December } 2021
$$


vaccine generally aims to reduce the transmission or transmission of Covid-19, reduce morbidity and mortality due to Covid-19, achieve group immunity in the community (herd immunity), while also protecting the community from Covid-19 so that they remain socially and economically productive. ${ }^{7}$

In each region, both at the provincial and district/city levels in Indonesia, through the government and private agencies and/or agencies, they have launched a vaccine implementation for workers and employees and in general for the wider community. The Southeast Maluku District government has also done the same thing through the Southeast Maluku District Health Office and other related institutions.

The Covid-19 vaccination achievement rate in Southeast Maluku Regency, Maluku Province, until early November 2021 only reached 42.32. Meanwhile, the national vaccination target that should be achieved is to reach 70 percent by the end of November 2021. Therefore, the Southeast Maluku Regency government continues to strive through the participation and contribution of both the sub-district and village governments (ohoi) to accelerate the covid-19 vaccination. to contain the spread of Covid- 19 .

Table 1. Data on the Covid-19 vaccination rate from the Southeast Maluku District Health Office shows that as of November 4, 2021

\begin{tabular}{|c|c|c|c|c|c|}
\hline \multirow[t]{2}{*}{ No. } & \multicolumn{2}{|c|}{$\begin{array}{c}\text { First Dose } \\
\text { Achievement }\end{array}$} & \multicolumn{2}{|c|}{$\begin{array}{l}\text { Second Dose } \\
\text { Achievement }\end{array}$} & \multirow{2}{*}{$\begin{array}{c}\text { Total Number of } \\
\text { Citizens Who Must Be } \\
\text { Vaccinated (Quantity) }\end{array}$} \\
\hline & Quantity & $\%$ & Quantity & $\%$ & \\
\hline 1. & 39.596 & 42.32 & 20.017 & 21.39 & 93.569 \\
\hline
\end{tabular}

Source : The data is processed from the Report of the Head of the District Health Office. Southeast Maluku in the Coordination Meeting for the Acceleration of Covid-19 Vaccination in Southeast Maluku Regency.

From the data described in the table above, it shows that the number of Covid-19 vaccination achievements for both the first and second doses has not even reached 50 percent. Moreover, the target set by the government until the end of November is 70 percent. One of the factors constraining the low rate of covid-19 vaccination in Southeast Maluku Regency is the legal awareness of the community to carry out covid-19 vaccinations. There are various reasons that are constraining factors so that people do not want to do this covid-19 vaccination, such as not believing in the covid-19 virus, not believing in the covid-19 vaccine drug related to the level of halalness, and there are also those who feel their body is in a state of weakness. In good health, there is no need to get vaccinated against COVID-19.

\section{Public Legal Awareness of the Importance of the Covid-19 Vaccination Program in Southeast Maluku Regency}

In the fourth paragraph of the Preamble to the 1945 Constitution of the Republic of Indonesia, it is stated that one of the goals of the state is to provide protection to the entire Indonesian nation and all of Indonesia's bloodshed. In the equivalent of the word "protect" here it means that the state is obliged to maintain and be responsible for welfare in all aspects of the life of the Indonesian nation. ${ }^{8}$ This includes protecting the Indonesian nation from the spread of the COVID-19 pandemic. The government through various declarations and implementation

7 https://anggaran.kemenkeu.go.id/in/post/penanggulangan-pandemi-covid-19-melalui-programpengadaan-vaksin-dan-pelaksanaan-vaksinasi-covid-19, accessed 13 September 2021.

8 Fauzia, A., \& Hamdani, F. (2021, July). Pendekatan Socio-Cultural dalam Pelaksanaan Vaksinasi Covid19 di Indonesia. In Seminar Nasional Hukum Universitas Negeri Semarang (Vol. 7, No. 1, pp. 323-338).

459|S A I Volume 27 Is u e 4, October - D e cember 2021 
of programs and policies to provide protection for the community in breaking the chain of covid-19, one of which is through the covid-19 vaccination program.

From the data in the discussion of point 1 above, it shows that the government is working on a vaccination program for a good purpose, namely breaking the chain of the spread of COVID-19, but on the other hand, people who still don't feel it is important to get COVID-19 vaccination. As happened in the community in Southeast Maluku Regency. In other words, the public's legal awareness to vaccinate against COVID-19 is still very minimal or low.

Basically, the law functions as the protection of the interests of the community, so that the interests of the community are protected. For this reason, in the implementation of law enforcement there are three elements that must always be considered, namely, legal certainty (Rechtssicherheit), expediency (Zweckmassigkeit) and justice (Gerechtigkeit). ${ }^{9}$ Meanwhile, legal problems in Indonesia can be caused by several things, including the judicial system, legal instruments, inconsistency in law enforcement, power intervention, and legal protection.

From the point of view of legal philosophy, that philosophy of law has a strategic function in the formation of a law-conscious and obedient society in Indonesia. Law is a benchmark for human science, or social science, because it is an integral and important part of the components of society and culture. Thus the law is one form of culture for the control and regulation of human behavior, either individually or collectively in its application. ${ }^{10}$

Considering that law is the main tool for social control in modern society as well as in primitive society, the formation of a law-aware and law-abiding society is the ideal of the existence of norms that want a just society so that the joints of the culture of society will develop towards the creation of a system of people who respect each other. For this reason, the law can be understood based on the opinion of each person, among others: "The law is the whole of the rules or the rules in a common life, the whole regulation of behavior that applies in a common life, which can be enforced with a sanction". ${ }^{11}$

With regard to "legal awareness" is defined separately in language which the basic word "aware" knows and understands, and as a whole is knowing and understanding the law. Some of the factors that influence people not to be aware of the importance of law are: "There is legal uncertainty and static regulations and inefficient ways of society to maintain applicable regulations.". 12

According to Ewick and Silbey: "Legal Consciousness" refers to the ways in which people understand the law and legal institutions, namely the understandings that give meaning to people's experiences and actions. ${ }^{13}$ For Ewick and Silbey, "legal consciousness" is formed in action and is therefore a matter of practice to be studied empirically. In other words, legal awareness is a matter of "law as behavior", and not "law as a rule of norms or principles". The importance of awareness to build a society that is aware of the law is expected to support and make people respect institutions or rules as a fulfillment of the need to crave obedience and law order. In relation to the implementation of the vaccination program in Southeast Maluku Regency, it is very clear that the legal awareness of the people of Southeast Maluku is still very low on the importance of covid-19 vaccination in order to break the chain of the spread of COVID-19.

9 Mertokusumo, S. (2007). Penemuan Hukum: Suatu Pengantar, Yogyakarta: Liberty, p. 145.

10 Marsinah, R. (2018). Kesadaran Hukum Sebagai Alat Pengendali Pelaksanaan Hukum Di Indonesia. Jurnal Ilmiah Hukum Dirgantara, 6(2).

11 Fuadi, M. (2013) Teori-Teori Besar (Grand Theory) Dalam Hukum, Jakarta: Kencana Penada Media Group, h. 40.

12 Satjipto, R. (1991). Ilmu Hukum, Bandung: Citra aditya Bakti, h. 112.

13 Ali, A. (2009). Menguak Teori Hukum (Legal Theory) dan Teori Peradilan (Judicial Prudence) Termasuk Interprestasi Undang-Undang (legisprudence), Jakarta: Kencana Penada Media Group, h. 510.

460|S ASI Volume 27 Issue 4, October - December 2021 
The Southeast Maluku Regency Government through the Health Office and other related agencies needs to work and strive with various better and more appropriate approaches so that awareness and legal compliance of the community to carry out COVID-19 vaccinations can be realized and in the end the target for COVID-19 vaccination is 70 percent in Southeast Maluk Regency by the end of November 2021 can be met. The fulfillment of the target of 70 percent of the Covid-19 vaccination in Southeast Maluku district means that more and more people in Southeast Maluku district are vaccinating against COVID-19, and it also means that public legal awareness of the importance of Covid-19 vaccination is getting better.

\section{CONCLUSION}

The implementation of the Covid-19 vaccination in Southeast Maluku Regency continues to be carried out in order to meet the national achievement target of 70\%. Until early November, it showed that the achievement rate of Covid-19 vaccination for both dose one and dose two had not yet reached 50 percent, so cooperation and contributions from all levels of society and the government were needed. By not fulfil the national COVID-19 vaccination achievement target in Southeast Maluku Regency, it shows that the legal awareness of the community to vaccinate COVID-19 in Southeast Maluku is still very minimal. The Southeast Maluku Regency Government needs to approach the community that is more humanistic and sociocultural in order to provide education and good understanding for the community about the Covid-19 vaccination so as not to cause doubts in the community to vaccinate COVID-19. Synergy, participation and good legal awareness from the community are also the main elements so that the spread of COVID-19 vaccination can be cut off through various government programs and policies, one of which is the Covid-19 vaccination.

\section{REFERENCES}

\section{Journal}

[1] Ayunda, R., Kosasih, V., \& Disemadi, H. S. (2021). Perlindungan Hukum Bagi Masyarakat Terhadap Efek Samping Pasca Pelaksanaan Vaksinasi Covid-19 Di Indonesia. NUSANTARA: Jurnal Ilmu Pengetahuan Sosial, 8(3), 194-206.

[2] Fauzia, A., \& Hamdani, F. (2021, July). Pendekatan Socio-Cultural dalam Pelaksanaan Vaksinasi Covid-19 di Indonesia. In Seminar Nasional Hukum Universitas Negeri Semarang (Vol. 7, No. 1, pp. 323-338).

[3] Marsinah, R. (2018). Kesadaran Hukum Sebagai Alat Pengendali Pelaksanaan Hukum Di Indonesia. Jurnal Ilmiah Hukum Dirgantara, 6(2).

[4] Pesulima, T. L., \& Hetharie, Y. (2020). Perlindungan Hukum Terhadap Keselamatan Kerja Bagi Tenaga Kesehatan Akibat Pandemi Covid-19. Sasi, 26(2), 280-285.

[5] Prajnaparamitha, K., \& Ghoni, M. R. (2020). Perlindungan Status Kerja Dan Pengupahan Tenaga Kerja Dalam Situasi Pandemi COVID-19 Berdasarkan Perspektif Pembaharuan Hukum. Administrative Law and Governance Journal, 3(2), 314-328.

[6] Rothan, H. A., \& Byrareddy, S. N. (2020). The epidemiology and pathogenesis of coronavirus disease (COVID-19) outbreak. Journal of autoimmunity, 109, 102433.

[7] Tjoanda, M., Hetharie, Y., Pariela, M. V. G., \& Sopamena, R. F. (2021). Covid-19 sebagai Bentuk Overmacht dan Akibat Hukumnya Terhadap Pelaksanaan Perjanjian Kredit. SASI, 27(1), 93-101.

\section{Book}

[8] Ali, A. (2009). Menguak Teori Hukum (Legal Theory) dan Teori Peradilan (Judicial Prudence) Termasuk Interprestasi Undang-Undang (legisprudence), Jakarta: Kencana Penada Media Group.

[9] Fuadi, M. (2013) Teori-Teori Besar (Grand Theory) Dalam Hukum, Jakarta: Kencana 461|SASI Volume 27 Issue 4, October - December 2021 
Penada Media Group.

[10] Mertokusumo, S. (2007). Penemuan Hukum: Suatu Pengantar, Yogyakarta: Liberty.

[11] Satjipto, R. (1991). Ilmu Hukum, Bandung: Citra aditya Bakti.

\section{Online/World Wide Web}

[12] https://anggaran.kemenkeu.go.id/in/post/penanggulangan-pandemi-covid-19-melaluiprogram-pengadaan-vaksin-dan-pelaksanaan-vaksinasi-covid-19. 